\title{
Author Correction to: Tube-dwelling in early animals exemplified by Cambrian scalidophoran worms
}

Deng Wang ${ }^{1,2}$, Jean Vannier ${ }^{2}$, Cédric Aria ${ }^{1}$, Jie Sun ${ }^{1}$ and Jian Han ${ }^{3 *}$

\section{Correction to: BMC Biol 19, 243 (2021) https://doi.org/10.1186/s12915-021-01172-4}

The original article [1] erroneously mentioned that Sullulika species was from Sirius Passet Lagerstätte.

The authors wish to clarify that it is instead from the Buen Formation in North Greenland.

\section{Author details}

${ }^{1}$ Shaanxi Key Laboratory of Early Life and Environments, State Key Laboratory of Continental Dynamics, Department of Geology, Northwest University, Xi'an 710069, China. ${ }^{2}$ Univ Lyon, Univ Lyon 1, ENSL, CNRS, LGL-TPE, F-69622 Villeurbanne, France. ${ }^{3}$ Shaanxi Key Laboratory of Early Life and Environments, State Key Laboratory of Continental Dynamics, Department of Geology, Northwest University, Xi'an 710069, China.

Published online: 01 February 2022

\section{Reference}

1. Wang $D$, et al. Tube-dwelling in early animals exemplified by Cambrian scalidophoran worms. BMC Biol. 2021;19:243. https://doi.org/10.1186/ s12915-021-01172-4.

The original article can be found online at https://doi.org/10.1186/s12915021-01172-4.

*Correspondence: elihanj@nwu.edu.cn

${ }^{3}$ Shaanxi Key Laboratory of Early Life and Environments, State Key

Laboratory of Continental Dynamics, Department of Geology, Northwest

University, Xi'an 710069, China

Full list of author information is available at the end of the article

(c) The Author(s) 2022. Open Access This article is licensed under a Creative Commons Attribution 4.0 International License, which permits use, sharing, adaptation, distribution and reproduction in any medium or format, as long as you give appropriate credit to the original author(s) and the source, provide a link to the Creative Commons licence, and indicate if changes were made. The images or other third party material in this article are included in the article's Creative Commons licence, unless indicated otherwise in a credit line to the material. If material is not included in the article's Creative Commons licence and your intended use is not permitted by statutory regulation or exceeds the permitted use, you will need to obtain permission directly from the copyright holder. To view a copy of this licence, visit http://creativecommons.org/licenses/by/4.0/. The Creative Commons Public Domain Dedication waiver (http://creativeco mmons.org/publicdomain/zero/1.0/) applies to the data made available in this article, unless otherwise stated in a credit line to the data. 